\title{
Guilleermo
}

de Pelsham

Artículo original ๖ Acceso abierto

\section{La figura de Beatriz como idealización poética en la Comedia de Dante Alighieri}

The figure of Beatriz as a Poetic Idealization in Dante Alighieri's Comedy

\author{
Víctor Hugo Vásquez Gómezi (iD) 숭 \\ Cristian Alejandro Benavides Guevaraii (i) \\ ${ }^{i}$ Universidad del Valle; Buga; Valle del Cauca; Colombia. \\ "i Instituto Técnico, Agropecuario y Forestal de Calima; El Darién; Valle del Cauca; Colombia.
}

Correspondencia: Víctor Hugo Vásquez Gómez. Correo electrónico: victor. vasquez@correounivalle.edu.co

Recibido: 23/01/2021

Revisado: 10/06/2021

Aceptado: 12/07/2021

Citar así:. Vásquez Gómez, Víctor Hugo; Benavides Guevara, Cristian Alejandro (2021). La figura de Beatriz como idealización poética en la comedia de Dante Alighieri. Revista Guillermo de Ockham, 19(2), pp. 307-320.

https://doi.org/10.21500/22563202.5237

Copyright: (C) 2021. Universidad de San Buenaventura, Cali. La Revista Guillermo de Ockham proporciona acceso abierto a todo su contenido bajo los términos de la licencia Creative Commons AttributionNonCommercial-NoDerivatives 4.0 International (CC BY-NC-ND 4.0).

Conflicto de intereses. Los autores han declarado que no hay conflicto de intereses.

Disponibilidad de datos. Todos los datos relevantes están en el artículo. Para mayor información contactar al autor de correspondencia.

Fondos. No.

Descargo de responsabilidad. El contenido de este artículo es responsabilidad exclusiva de los autores y no representa una opinión oficial de sus instituciones ni de la Revista Guillermo de Ockham.

\section{Resumen}

Este artículo tiene como objetivo examinar si la representación poética de la figura de Beatriz en la Comedia se corresponde con el si mismo dantesco a la manera de una proyección, de una ensońación idealizada. A partir de los estudios sobre el fenómeno de la ensońación poética de Gastón Bachelard y los de C. G. Jung sobre los sueños y la naturaleza andrógina del alma humana (anima anima-animus), se hace una lectura en perspectiva crítico hermenéutica de la Comedia, considerando dos interrogantes principales: ¡cuál es el estatuto psíquico de la ensoñación dantesca? Y ¡cuál es la simbología que entraña el ideal femenino de Beatriz y que el mismo Dante - por no poseer- desea y proyecta poéticamente? Se argumenta que la Comedia puede entenderse como un elogio del sumo amor idealizado, interpretando que los valores expresados en las palabras y en el êthos de Beatriz no son más que la proyección del anima dantesca, es decir, que desde la teoría de la ensońación poética de Bachelard, Beatriz se erige como una idealización del deseo de virtud del propio Dante.

Palabras clave: poesía, literatura, comedia, filosofía y ética, símbolo, amor, representación, sueño.

\begin{abstract}
This article aims to examine whether the poetic depiction of Beatriz's character in The Comedy correlates with a projection of the author himself, as an idealized reverie. A criticalhermeneutical reading of Dante's Comedy is made herein based on Gastón Bachelard's studies on the phenomenon of poetic reverie, as well as on C. G. Jung's on dreams and the androgynous nature of the human soul (anima-animus). The article takes two main questions into consideration: What is the psychic status of Dantean reverie? And, what is the symbolism that the female ideal of Beatriz poetically projects? It's been argued that The Comedy can be understood as a praise of the highest idealized love, while construing that the values expressed in Beatriz's ethos and words are nothing more than a projection of the anima of Dante himself, that is to say, that in Bachelard's theory of poetic reverie, Beatriz stands as an idealization of Dante's own desire for virtue.
\end{abstract}

Keywords: poetry, literature, comedy, philosophy and ethics, symbol, love, representation, dream. 


\section{Introducción}

\author{
Yella, que me veía cual me veo \\ yo mismo, por templar mis emociones, \\ la boca abrió sin aguardar careo \\ y comenzó: "Te crea confusiones \\ tu falso imaginar, y no estás viendo \\ lo que verias libre de ilusiones».
}

(Alighieri, Par. I, 85-90)

Estos versos con los que a modo de epígrafe abrimos este texto, son, de alguna manera, reveladores para justificar que, desde esa enorme catedral literaria que es la Comedia, es posible hallar elementos de relevancia para entender la presencia de una idealización ensońadora en Dante a partir de la figura de Beatriz. Concepto este que tomamos prestado de la poética filosófica de Gastón Bachelard (2014) y a su vez, sustentado en buena medida por las aportaciones de la psicología de Carl Gustav Jung (1970) en la constitución del arquetipo anima. A la luz de lo anterior, interesa comprender desde el plano poético, la importancia que tiene la potencia femenina del anima en la mujer amada de Dante, Beatriz, figura ${ }^{1}$ femenina idealizada en la que el florentino proyecta unos valores de virtud emanados de su yo deseante. Más preciso, cuando el Dante poeta escribe: "Y ella, que me veía cual me veo/yo mismo (...)” (Par. I, 85-86) está manifestándose no solo su alma creadora (anima), sino la compleja identidad de su yo creador consigo mismo, pues únicamente su Beatriz puede verlo como él se ve. Los siguientes interrogantes conforman los momentos esenciales de este texto, a saber, ¿cuál es el estatuto psíquico de la ensońación dantesca?, ¿qué es lo que su Beatriz ve en su Dante?, ¿cuál es la simbología que entrańa el ideal femenino de Beatriz y que el mismo Dante por no poseer, desea y proyecta poéticamente en sí mismo?

En aras de ir aperturando conceptualmente el ejercicio crítico hermenéutico, se plantean, en el marco de esta introducción, unas primeras consideraciones sobre el concepto de ensońación idealizante y la manera como esta se imbrica en los postulados jungianos en torno a los arquetipos. En Poética de la ensoñación (2014), Bachelard desarrolló un análisis fenomenológico del alma, a la que le adjudicó un valor andrógino. Para ello, el filósofo francés distinguió entre la forma en que el sueño y la ensoñación operan en la psiqué humana. Al primero, Bachelard lo identificó como una potencia masculina: el animus; y al segundo, como el anima, cuya esencia es femenina. De este modo, las imágenes que se proyectan en el estado onírico se bifurcan en aquellas que escapan al control del sońador, como ocurre en el sueño, y aquellas que se generan en la vigilia, de las cuales se tiene plena conciencia. En el caso de estas últimas imágenes, al decir de Bachelard, puede vislumbrarse en la ensoñación un potencial creador, pues emana de la energía femenina (Bachelard, 2014, p. 84 y ss.).

Por su parte, el binomio animus-anima se erige como un principio constitutivo de la psiqué humana, que Carl Gustav Jung (1970) ya había estudiado en su texto Arquetipos e inconsciente colectivo. Los contenidos del inconsciente colectivo, de acuerdo con Jung, son los arquetipos, esto es, contenidos psíquicos no sometidos a elaboración consciente

1. Usamos el término "figura" en su acepción latina de figūra f.: estructura, configuración, forma (figura corporis nostri, la configuración de nuestro cuerpo; esse humana specie et figura, tener el aspecto y configuración humanos. Cf. Diccionario VOX Latino-Español (1982). Las razones son, por un lado, poéticas y, por el otro, teológicas. Al margen de si hubo o no una Beatriz histórica, en el contexto de la Comedia es esencialmente una ficción poética, una metáfora, una configuración. Y en un plano teológico, Beatriz es un alma que habita las regiones del Purgatorio y el Paraíso; es decir, está exenta de corporeidad, pero su alma tiene forma humana. 
alguna. El arquetipo es, entonces, una representación ya inserta en la experiencia del sujeto; sus imágenes están planteadas en él a priori, pues el hombre no hace un ejercicio racional sobre sus significados. En el caso particular del arquetipo del anima, Jung sostiene que este opera a nivel psíquico, del cual la experiencia humana es su fuente; psiqué y mundo en proceso dialógico (Jung, 1970, pp. 51-52).

De esta manera, puede verse cómo Bachelard se vale del anima jungiana, toda vez que para este el anima es una potencia femenina que se eleva como imagen universal y se proyecta como arquetipo. En el caso que nos ocupa, aseveramos que Dante proyecta en Beatriz lo que su inconsciente le dicta en términos de idealización. Dicho de otra manera, la proyección arquetípica del anima en Jung se identifica con la ensoñación idealizante en Bachelard, cuyo correlato advierte que en la ensońación del poeta, el dialogismo animusanima configura una proyección psicológica sobre aquello que se ama u odia, mediante un proceso que traslada a otro su propio yo.

Para llevar a cabo lo anterior, se procede, primero, efectuando un estado de la cuestión considerando los estudios críticos especializados sobre la relación Dante-Beatriz. Segundo, explicamos los conceptos centrales que constituyen el objeto del análisis, como los de ensońación poética, anima-animus, idealización poética, deseo y proyección del sí mismo. Por último, interpretamos los pasajes de la Comedia en los que la figura de Beatriz se hace presente en sintonía con nuestro punto de vista, según el cual el ideal femenino de Beatriz es, desde la teoría de la ensońación poética de Bachelard, una proyección de Dante mismo, una representación poética del deseo de virtud y perfección moral que el poeta florentino añora.

\section{Unas significaciones de la figura de Beatriz en la obra de Dante: un estado de la cuestión}

Así pues, el problema de la significación de Beatriz en la obra de Dante es diverso y ha generado discusiones en el orden poético, filosófico, teológico, ${ }^{2}$ psicológico entre algunos especialistas. He aquí un estado de la cuestión. Scrimieri (2008), en su texto Imágenes y visiones de Beatriz se aboca al estudio de la proyección arquetípica del alma de Dante en Beatriz, de ahí que aborde la significación y la naturaleza de las apariciones de la donna, planteando que su aparición nunca se da de manera inmediata, esto es, como una presencia viva en el mundo (p. 46).

De hecho, según la autora, en las obras objeto de su análisis, como Vita nuova, la Comedia y el Convivio, Beatriz es una presencia abandonada a visiones e imágenes del recuerdo. Así pues, la imagen de la donna que Dante proyecta en su ejercicio poético, es la de una donna ya muerta, lo cual le permite, según Scrimieri, "una elaboración fantástica, según los movimientos y exigencias de su imaginación” (2008, p. 46). Por lo tanto, esta facultad transforma las imágenes en el modo de cómo aparecen en el recuerdo, debido a los componentes anímicos que el poeta proyecta sobre ellas. ${ }^{3}$

En ese sentido, por la manera como aparece Beatriz en los escritos de Dante, aquella se concibe como una "gloriosa donna de la mente" (p.46), en cuanto se representa como un

2. Un ejemplo de esto es la lectura de Santayana (1943), quien sostiene que Beatriz "es indudablemente la teología" y que simboliza el sendero de la salvación (p. 92).

3. Resulta interesante observar cómo antes de esta interpretación de Beatriz como donna fantasmal, Scrimieri habría escrito un artículo titulado La analogía Beatriz-Cristo, en el cual desarrolla un análisis del símbolo en aras de considerar la función de los intertextos evangélicos en la Vita nuova de Dante, así como sus efectos analógicos entre Beatriz y Cristo. Así, Scrimieri considera la Vita Nuova, a partir de la concepción del símbolo jungiano, puesto que tal visión posibilita la apertura hacia aspectos no claramente conocidos. Para ello recurre al principio de individuación de Jung, el cual está articulado a una serie dinámica de símbolos e imágenes arquetípicas que decantan en los símbolos del sí mismo y de la imagen de Dios. 
movimiento de traer al presente aquellas imágenes recluidas en el fondo de la memoria, con la intención de transformarlas a través de un ejercicio poiético que cristaliza y toma forma en el arquetipo del anima, con todos los aditamentos en que este puede aparecer, pues tiene sus raíces anquilosadas en los recodos del inconsciente. Beatriz aparece, entonces, como fantasma, como una donna fantasmal que al morir empieza a fraguarse en la mente de Dante y cuyo hábitat es su propia alma aquí en la tierra.

De acuerdo con lo anterior, Scrimieri (2008) asevera que la forma como se puede interpretar el vivir fantasmal de Beatriz en la mente de Dante, cuyas proyecciones cristalizan por medio de las maneras como la imaginación se manifiesta, ya sea en sueños, visiones y ensoñaciones, es considerarla como símbolo arquetípico que ve en ella la proyección del arquetipo del anima. De este hecho se desliga la idea que ve en Beatriz una imagen recurrente pero no inmutable; es decir, una imagen móvil y cambiante imbricada en los aspectos del arquetipo que el poeta proyecta sobre ella. En ese orden, el trayecto vital y poiético de Dante determina las diferentes maneras como la donna puede aparecer, pues encarna diversos momentos anímicos. De ahí que: "El arquetipo es móvil y polivalente y así también lo es la imagen de Beatriz. No hay una Beatriz, sino varias beatrices” (p. 46).

Por otro lado, Miller (2009) en su estudio ¿Quién es Beatriz? Las cualidades de una mujer, plantea que Beatriz es una de las mujeres más destacadas de la tradición judeocristiana de la Europa Mediterránea, cuya aparición refulge en la Comedia de Dante Alighieri. En esa medida, Miller se pregunta quién es Beatriz y para darle respuesta a su interrogante abre dos líneas de análisis. La primera tiene que ver con las cualidades de la donna como figura ejemplar, y la otra, "con los valores representados por medio de la representación poética de ella para nuestra consideración” (Miller, 2009, p. 441). De hecho, advierte si esos valores que cristalizan en la figura de Beatriz pueden ser asumidos como un ejemplo para ser imitado en la cultura, dado su carácter de mujer ideal en la civilización occidental.

Miller desancla a Beatriz de todo carácter pagano y por tanto pecaminoso. Escinde a la Beatriz histórica, esposa del banquero Portinari de Florencia en el Trecento, de la "bella creación poética, filosófica, pedagógica, política y teológica de Dante Alighieri" (p. 442). En ese sentido, Beatriz no es una femme fatal, una cortesana ni una amante. Es ante todo, "la imagen bella objeto de amor, estricta, honorable, casta de un ideal. Pero, ¡cuál ideal? (p. 442).

En aras de resolver cuál es el ideal de mujer que representa Beatriz, Miller se instala en los dos primeros capítulos de la cántiga del Infierno. En este proemio al reino de la prisa, ${ }^{4}$ se observa la turbación de Dante, pues se ha encontrado con tres criaturas que le cierran el paso $0^{5}$ que simbolizan su distanciamiento de Dios.

Sin embargo, es en este episodio del poema cuando hace aparición el poeta latino Virgilio. Tal aparición del mantuano tiene que ver con un plan orquestado desde los cielos del Paraíso (Comedia I, 121-123). Así, Beatriz ha dejado el reino de la luz y ha puesto su mirada en el Infierno, cumpliendo así una petición de la Virgen María a través de Santa Lucía. Esto es, La Virgen, Santa Lucía y Beatriz han configurado un trinomio femenino que conspira de manera misericordiosa en favor de Dante, con el fin de ayudarlo en su miseria terrenal (Miller, 2009, p. 442).

Miller denomina como tríptico a la unión de estas tres mujeres y advierte para cada una un tipo de representación. En efecto, la Virgen María representa la misericordia; Santa

4. Tal es el calificativo que le da Ángel Crespo debido a la rapidez con que Dante y Virgilio recorren el Infierno. (Crespo, 1999, p. 95)

5. El leopardo, el león y la loba. Estos tres animales simbolizan, respectivamente, la lujuria, la soberbia y la incontinencia; pasiones que habría sufrido Dante. (Comedia, I, 31 - 54) 
Lucía, la patrona política de la naciente Italia y, por último, Beatriz, la personificación del amor humano y sagrado que insulla en el Dante pecaminoso el aspecto más humano hacia Dios (p. 442). Esto es, Beatriz como mediadora entre el cielo y la tierra y como objeto del amor más profundo y, por tanto, portadora del alma y la mente del poeta.

Así, como parte de un complot celestial, Beatriz se encarga de apoyar y promover el amor hacia Dante, pero según Miller, este está emparentado con un tipo de amor "más parecido a caritas (el buen uso de las cosas del mundo y el amor misericordioso que conduce a Dios)" ${ }^{\prime \prime}$ (p. 443), por oposición al amor cupiditas, cimentado en el egoísmo, la avaricia y la lujuria; esto es, el mal uso de las cosas del mundo.

Llegados hasta aquí, comentamos otro estudio que se acerca a nuestra postura aunque mantenemos diferencias. Bejarano (2006), plantea un análisis que tiene como eje la articulación de dos textos fundamentales: La poética de la ensoñación, de Gastón Bachelard y Arquetipos e inconsciente colectivo, de C. G. Jung. Esto con el fin de abordar las nociones de ensoñación y su imbricación con el arquetipo del anima como cristalización del ensoñador de palabras.

Bejarano señala que Bachelard parte de una androginia del alma, de una disposición establecida sobre la base del animus y el anima. En lo concerniente al anima, la autora aduce que en el alma del poeta prevalece más una proyección anímica. Se da una inclinación hacia el torrente poético advenido por una ensoñación que emana del lado femenino de las almas (Bachelard, 2014, p. 73). Dicho esto, Bejarano señala una "petrificación" de las cosas, es decir, la manera como estas quedan atrapadas por virtud del significado que las expresa. Sin embargo, según Bachelard existen unos seres adánicos; unos seres que tienen la facultad de ponerles nombre a las cosas e, incluso, desnombrarlas: los poetas.

Así las cosas, el poeta es quien ensueña y su ensoñación la constituyen las palabras. En el estado anímico del alma se le da una significación a las palabras partir de su género. Esto es, el poeta es uno de los seres que pueden captar su feminidad. Cabe acotar que desde Bachelard se concibe las palabras como seres animados, puesto que tienen ser. Y de acuerdo con Bejarano, las palabras han perdido su carácter antinómico válido para construir el onirismo. Para ejemplificarlo, cita un apartado del paraíso de la Comedia, de Dante:

Allí mañana y noche aquí había hecho/tal hueco, y casi todo allí era blanco/el hemisferio aquel, y el otro negro/cuando Beatriz hacia el costado izquierdo/vi que volvía y que hacia el sol miraba:/nunca con tal fijeza lo hizo un águila. (Paraíso I, 46.)

De acuerdo con Bejarano, el fragmento citado plantea un equilibrio en cuanto a términos antitéticos: mañana, noche; blancura, oscuridad. Sin embargo, aduce que en Beatriz cristaliza una visión arquetípica de la mujer "[...] como bien, como ideal de sabiduría, como belleza” (Bejarano, 2006, p. 62). Es menester advertir que la autora no se detiene en este apartado, puesto que el estudio fenomenológico del que parte tiene como objetos la poesía de Octavio Paz y Rosario Castellanos y Rayuela, de Cortázar.

Por su parte, Ginés (2012), plantea un asunto que desde la antigua Grecia aparece como leitmotiv en las discusiones sobre el género poético: el del poeta y la musa. Desde Homero a Jhon Milton, la musa inspiradora se asume como dadora de palabra, de influjo creador. Así, Ginés advierte que la musa inspiradora de Dante fue Beatrice Portinari.

De acuerdo con la autora, en el transcurso surgieron nuevas teorías que concebían a Beatrice no como un personaje histórico, sino como "[...] la representación de la teolo-

6. Interpretación que coincide con la de Collazos (2013), quien interpreta a Beatriz como un modelo de amor que a través de la orientación de Virgilio, aguarda unirse con Dante en el Paraíso. Beatriz, en este sentido, es promesa de unidad espiritual y moral, i.e., de felicidad. 
gía, encarnada en la perfecta beata" (Ginés, 2012, p. 319). Huelga advertir que son los hijos de Dante quienes adelantaron estos niveles hermenéuticos. Para Pietro Alighieri, por ejemplo, Beatrice sería símbolo de la ciencia divina. Sin embargo, de acuerdo con Ginés, Pietro abandonaría tal concepción para destacar la existencia histórica de quien fuera el amor de la vida de su padre. ${ }^{7}$

De otro lado, en un estudio reciente (2019) titulado Dante Alighieri e a voz femenina sobredeterminada: agonismo e fantasmagoria, Pedro Carlos Louzada (2019), pone de relieve el tránsito y la concepción que Dante hace de la figura de Beatriz desde la Vita nuova a la Comedia. Para este autor, Beatrice se erige como una figura "[...] dotada de voz masculina do próprio Dante em constante processo de autoescuta” (p. 201). Para llevar adelante este tránsito, Louzada elabora un ejercicio hermenéutico de contrapunto entre la forma como aparece la figura de Beatriz en la Vita nuova y la Comedia. De entrada, advierte que mientras en el primer texto Beatriz se concibe como la figura del amor idealizado, en la Comedia tal sentimiento se sublima en aras de la realización poética suprema de Dante.

Uma das importantes características temáticas dessa separação consiste exatamente em situar o papel da mulher, que passa de figuração do amor idealizado em Vida nova para a sublimação desse sentimento como realização da obra como potência na Comédia, ou seja, a realização do poeta num plano muito mais próximo da centralidade estética e canônica, da supremacia do gênio poético de Dante que ultrapassa qualquer identificação teológica do amor cortês medieval. O que se vê na Comédia é a realização suprema do poeta Dante [...]. (p. 202)

Así las cosas, según Louzada resulta claro que la Beatriz que habla en la Vita nuova o en la Comedia, no es una mujer a la que Dante vio un par de veces, sino que es el receptáculo del propio torrente poético de Dante puesto en boca de su musa. Esto es, Beatriz se erige como una proyección poética del mismo Dante, en virtud de la cual el poeta italiano halla su verdadero tono poético.

O que se ouve pela boca de Beatriz, mesmo quando alçada ao mais alto dos círculos do Paraíso, não é senão a própria voz do poeta encarnado na figura de sua musa. E essa inversão permite a Dante encontrar no ato de cantar em nome de sua musa seu verdadeiro tom poético. (p. 205)

Al decir del autor, lo que hace Dante es reconfigurar la dama trovadoresca dejándola en el umbral de una hibridez particular para la época, en cuanto se proyecta en una figura femenina una voz masculina p. 205). De acuerdo con Louzada, esta figura es sui generis en el panorama poético de la literatura occidental. Así, Beatriz es una dama con voz masculina que no deja "[...] centralizar todas as suas açóes e fala em torno de Dante como poeta supremo" (p. 205).

De parte nuestra y a manera de discusión, en Scrimieri (2008) destacamos una cercanía con nuestra interpretación que concibe a Beatriz como proyección del mismo Dante. Sin embargo, la autora no da cuenta de cuáles serían esos aspectos o valores que identifican a ambas figuras. ¿Qué es, específicamente, lo que proyecta Dante en esa donna fantasmal? Asimismo, coincidimos con Miller (2009) cuando destaca una proyección de Dante en Beatriz partir del valor del amor. Pero al igual que Scrimieri, no profundiza en cuáles serían esos otros valores que Dante otorga a la donna idealizada: ¿la beatitud?, ¡el conocimiento?, ¡la felicidad?

Con relación a los alcances de la investigación de Bejarano (2006), consideramos que si bien ofrece una mirada adecuada de la ensoñación poética, carece de un análisis profundo y específico de la Comedia, y su interés se centra el estudio fenomenológico

7. La autora cita la interpretación que Pietro Tartani hizo de Beatrice en La Beatrice Di Dante e la Bice Portinari, 1885. Para este crítico, es cuestionable la veracidad del nombre de la donna, por cuanto el revelamiento de este sería una excepción que rompe con la tradición Dolcestilnovista y anterior a ella (p. 319). 
de la poesía de Octavio Paz y Rosario Castellanos y Rayuela, de Cortázar. Ahora bien, la investigación de Ginés (2012), aborda la figura de Beatriz desde la complejidad de su existencia real concreta en la vida del poeta. Así, problematiza el hecho de la nominación de la donna y la carencia de descripciones físicas, lo que supone, para ella, el puente con las representaciones pictóricas hechas por Dante Gabriel Rossetti. Sin embargo, no se centra en el estudio de la representación de Beatriz por Dante, y más aún, qué podría simbolizar.

Por último, el estudio de Louzada (2019) se acerca a nuestra tesis en la medida en que concibe a Beatriz como una proyección poética del mismo Dante, mediante la cual el poeta habla y se realiza en toda su potencia poética. Beatriz es, entonces, el medio por el que Dante proyecta su voz masculina en aras de configurar la obra. Sin embargo, Louzada no ve en la proyección dantesca una proyección idealizante que conciba a Beatriz como todo lo que el poeta no tiene y que, por tanto, desea tener.

En definitiva, nuestra distancia hermenéutica frente a estos estudios radica, principalmente, en la fundamentación teórica que utilizamos, a saber, la comprensión de la figura de Beatriz partir de la ensońación poética de Bachelard, que explicamos a continuación.

\section{La ensoñación idealizadora: a propósito de la poética de Gaston Bachelard}

Por lo dicho hasta ahora y en aras de sentar unas posibles salidas a las cuestiones planteadas, es menester, en primer, lugar una conceptualización más precisa sobre lo que es la ensoñación idealizante y el grado de participación que tiene la psicología de Jung en ello. Así pues, en su Poética de la ensoñación (2014), Bachelard establece una diferenciación entre el sueño común que tenemos en la noche y la ensońación que se da en la vigilia. Las imágenes que se producen durante la noche escapan a nuestro control, mientras que la ensońación en la vigilia depende tanto de la sensibilidad del poeta como del lector, pues leyendo también se ensueña con palabras. Aunque en sentido amplio, tanto el sueño -y sus imágenes- como la ensoñación -y sus imágenes- forman parte como tal del estado onírico. De ahí que el punto diferenciador más relevante sea que desde el punto de vista de lo que él llama psicología de las profundidades, ${ }^{8}$ el sueño corresponde al animus, es decir, que es, esencialmente, masculino, mientras que la ensońación corresponde al anima, esto es, es femenina. Se explica esto por una razón, a saber, la ensońación al ser femenina -anima- es fundamentalmente creadora; el sueño no. El sueño es virilidad e intelecto (p. 84 y ss.).

Anima-animus son, pues, dos principios constitutivos de la psiqué humana, conceptos que toma Bachelard de la psicología de C. G. Jung, especialmente de su obra Arquetipos e inconsciente colectivo (1970, p. 49 y ss.). En sentido estricto, para Jung el concepto de anima no es un concepto teórico sino empírico, lo que sugiere que es susceptible de identificar y caracterizar partir de observaciones psíquicas. Y su naturaleza, lejos de pertenecer únicamente al ámbito médico, corresponde a todos los ámbitos de la experiencia humana: a lo personal, a lo social, al fenómeno del mundo en general: "O sea, que si queremos comprender qué es psique tenemos que incluir en nuestra comprensión el mundo" (Jung, 1970, pp. 51-52). Así, anima se enmarca dentro de lo que Jung llama arquetipos, imágenes universales que constituyen nuestro inconsciente. Por eso, insiste en que con esta expresión latina se designa algo que no debe ser confundido con ninguno

8. La "psicología de las profundidades" es una denominación que usa Bachelard para referirse a uno de los aspectos importantes en el psicoanálisis de C. G. Jung (1970). De manera más precisa, denota el inconsciente de la psiquis humana, aquello que constituye la vida interior y cuyas manifestaciones se presentan en la exterioridad del sujeto, en sus acciones, en sus complejos, en sus fobias, así como en sus opiniones y proyecciones. 
de los conceptos cristiano-dogmáticos, ni tampoco con ninguno de los que ha creado hasta ahora la filosofía (p. 54).

Del texto de Jung (1970), tomamos como características esenciales para efectos de nuestra lectura de Bachelard y, por supuesto, de Dante, dos: 1. la feminidad que constituye a anima, y 2. su proyección como arquetipo. Sobre lo primero aclara que anima debe verse como una parte femenina y ctónica del alma (p. 55), y esta definición es fundamental para entender su papel en la psicología masculina.

El anima es un factor de la mayor importancia en la psicología masculina, en la que siempre están en obra emociones y afectos. Fortifica, extrema, adultera y mitologiza todas las relaciones emocionales que se establecen con la profesión y con gente de ambos sexos. Las formaciones subyacentes de la fantasía son su obra. Si el anima está constelizada en mayor grado, afemina el carácter del hombre y lo hace sensible, susceptible, caprichoso, celoso, vanidoso e inadaptado. (Jung, 1970, p. 67)

Esta cualidad de anima para afectar la virilidad, i.e., para sensibilizarla, constituye lo que para Jung se denomina syzygias, parejas andróginas de los dioses en la mitología antigua que se aparean entre sí y que sirven de modelo para entender las dos potencias de la psiqué humana. ${ }^{9} \mathrm{Y}$ su concepción de la universalidad de este arquetipo está basada también en sus lecturas del gnosticismo y la filosofía china. ${ }^{10}$

Ahora bien, sobre la segunda característica, a saber, el fenómeno de la proyección, Jung explica que es "un proceso inconsciente, automático, por el cual un contenido inconsciente para el sujeto es transferido a un objeto, de modo que este contenido aparece como perteneciente al objeto.” (p. 55). En otros términos, esta definición sobre la proyección podría tener alguna conexión, en el terreno poético, con lo que para Bachelard se denomina ensońación idealizadora.

Para explicarlo mejor, de acuerdo con Bachelard nuestra alma tiene una doble naturaleza: es tanto masculina como femenina, es decir, somos seres psíquicamente andróginos (2014, p. 92 y ss.). Lo esencial y que interesa a este autor es, pues, descubrir, en esa unidad indisoluble, qué aspectos de la vida proceden a manera de impulsos y figurado en palabras, de lo masculino y de lo femenino. De ahí la tesis: "La ensońación está puesta bajo el signo del anima. Cuando la ensońación es realmente profunda, el ser que viene a sońar en nosotros es nuestra anima". (p. 97), lo anterior, aplicado a las ensoñaciones de y con las palabras. Se reconoce, entonces, que en la representación poética todo creador, y por extensión todo lector, ha de tener esa sensibilidad para plasmar o reconocer en primera instancia lo femenino -entiéndase, en anima- la ensoñación, sin pretender abandonar la androginidad esencial. De ahí que, según Bachelard, para Jung "el inconsciente no es un consciente rechazado, no está hecho de recuerdos olvidados; es una naturaleza primera. El inconsciente mantiene, pues, en nosotros sus poderes de androginidad". ${ }^{11}$ (p. 91)

Bachelard afirma que, incluso en el hombre más viril, caracterizado por un animus fuerte, también existe un anima y esto seńala la presencia de la androginia. Pero debido

9. De nuestra parte, conjeturamos muy plausible que este tipo de observaciones le hayan valido a Bachelard, para elaborar en el seno de sus estudios sobre la poesía, un concepto de androginidad inherente al alma humana, fundamental para entender la creación poética.

10. Jung alude, sin profundizar, al par de conceptos cosmogónicos yang (masculino) y yin (femenino) como ejemplo de androginia originaria. Y luego escribe para justificar su concepción de arquetipo colectivo que: "Con toda tranquilidad se puede afirmar que estas syzygias son tan universales como la aparición del hombre y la mujer. Este hecho autoriza evidentemente a concluir que la imaginación está sujeta a este tema de tal modo que en todos los lugares y todos los tiempos se ve llevada (psiqué) a volver a proyectar siempre lo mismo". (Cf. Jung, 1970 , p. 55).

11. Quizá, el aporte de Bachelard en esta psicología de la poesía que revisamos con ocasión del poema dantesco, se deba a la introducción del concepto de animus con el cual establece la doble manifestación del alma humana, es decir, la androginia que le es constitutiva: anima-animus. 
a las determinaciones sociales y cotidianas (se entenderá por Jung: arquetípicas), ${ }^{12}$ esta mezcla de los sexos es rechazada, excluida, de manera que se nos enseńa a ser hombres o mujeres sin más. Ahora bien, frente a estas aseveraciones no se está exento de objeciones por parte de las ciencias que soportan la objetividad y cientificidad.

En efecto, se nos podría observar-siguiendo el automatismo que padecen tantas dialécticas filosóficas- que si el hombre centrado sobre el animus sueña su ensoñación en anima, la mujer centrada sobre el anima debería soñar en animus. Sin duda, la tensión de civilización es hoy tal que el "feminismo" refuerza generalmente el animus de la mujer. (p. 97)

Pero la ensońación no busca la reivindicación de los géneros sino su constante comunión. Cabe recordar que Bachelard desarrolla este estudio basándose en el método fenomenológico, lo cual implica que el lenguaje, las palabras, son un fenómeno que tiene existencia y por esa razón es susceptible de analizarse porque puede develarse; se nos muestra como objeto de estudio: "También las palabras sueñan" (p. 36). Esto podría significar que nuestra realidad, lo que concebimos como real, solo es posible en su plena belleza y profundidad con el lenguaje que nos es propio, las palabras. Es decir, no existe para el hombre más realidad que la que habita en ellas, en los mundos que ellas crean.

Así pues, el concepto de ensońación idealizadora se usa para explicar que en la ensońación del poeta, la dialéctica del anima-animus es una suerte de proyección psicológica, aunque también cabría pensar en una proyección del deseo respecto a un objeto amado o un objeto odiado. Este punto goza de gran complejidad, ya que se entiende que toda idealización ha de buscar proyectar lo que uno no es en otro ser o en otra cosa.

El hombre que ama a una mujer "proyecta" sobre esta mujer todos los valores que venera en su propia anima. Y, de la misma manera, la mujer "proyecta" sobre el hombre que ama todos los valores que su propio animus querría conquistar. (...) La gente se ama con el mayor idealismo, encargándole al otro que realice la idealidad tal cual él la sueña. Así, en el secreto de las ensońaciones solitarias se animan, no las sombras sino los resplandores que iluminan el alba de un amor. (pp. 114-115)

Esto significa que en la ensoñación poética se identifican, mediante el ser de las palabras, la imagen del ser amado, idealizado.

Es la vida dentro de un doble, por un doble, una vida que se anima en una dialéctica íntima de animus y de anima. El doblar y el desdoblar intercambian su función. Doblando nuestro ser al idealizar al ser amado, desdoblamos nuestro ser en sus dos potencias de animus y de anima. (p. 121)

La ensońación, por lo tanto, aviva la potencia creadora; estimula la poiesis que fabrica imágenes idealizadas y debido a ello, en el objeto figurado mediante palabras, también se reproduce la imagen de sí mismo. Este es el sentido profundo de la ensoñación poética que experimenta el ensoñador de palabras. Traslada su propio yo y sus deseos a un objeto y esa duplicidad contiene, al mismo tiempo, "un doble de una infinita bondad (anima) y de una gran inteligencia (animus)" (p. 138).

\section{Dante y la idealización de Beatriz como proyección de sí mismo}

¿Cuál es la simbología que entrańa el ideal femenino de Beatriz y que el mismo Dante, por no poseer, desea y proyecta poéticamente? Para responder a este interrogante es pertinente comenzar por advertir que ante este intento nuestro por defender una proyec-

12. "He elegido la expresión "colectivo" porque este inconsciente no es de naturaleza individual sino universal. Es decir, en contraste con la psiqué individual tiene contenidos y modos de comportamiento cum grano salis, los mismos en todas partes y en todos los individuos. En otras palabras, es idéntico a sí mismo en todos los hombres y constituye así, un fundamento anímico de naturaleza suprapersonal existente en todo hombre" (Cf. Jung, 1970, p. 10). 
ción de valores y deseos idealizados en la Beatriz ficcionada del Dante poeta, no faltaría quien afirmara que esta tesis es imposible y hasta impertinente, pues de ningún modo las situaciones, las acciones y los caracteres representados poéticamente se corresponden con los deseos, la historia y el carácter del autor. ${ }^{13}$

En efecto, alegaría que el Dante histórico, el Dante vivo, no bajó al Infierno ni ascendió al Paraíso, como sí lo logró el Dante héroe. Nosotros responderíamos, primero, que la identificación entre Dante vivo y Dante héroe no es físico-histórica, pero sí psíquica y simbólica, pues no nos interesa saber si la Beatriz que imaginó sea exactamente la misma Beatriz histórica y real, sino lo que esta representa para Dante. Segundo, que lo que Dante escribió fue una suerte de expresión de su "pulsión de vida" ante la repentina e infortunada muerte de la Beatriz histórica a quien probablemente conoció y amó en secreto. ${ }^{14} \mathrm{Y}$ esto último es importante porque la Comedia, al lado de todas las interpretaciones que históricamente ha tenido y los distintos niveles de lectura que permite, ${ }^{15}$ puede considerarse como un elogio del sumo amor idealizado no correspondido, interpretando que la suavidad, la ternura y los valores expresados en las palabras que aluden a Beatriz no son más que la proyección del anima dantesca. Tercero, que en el plano de lo que Bachelard llama ensoñación poética, diremos que el lenguaje expresa la androginia inherente al alma humana y que un rasgo esencial de esta ensoñación es la idealización de otro u otra como uno mismo.

Dicho esto, señalamos que, en cuanto que Beatriz está presente en el Purgatorio y en el Paraíso -pues es quien acompaña y guía al poeta en la ascensión espiritual- los versos que siguen aportan a nuestro punto de vista.

En Purgatorio XXX se halla Dante en la Floresta Divina, lugar de especial importancia dado que emerge la figura de Beatriz para acompañar al poeta hacia la ascensión al Paraíso. Luego de una metáfora de la salvación del hombre mediante la imagen del septentrión que guía a los navegantes, Dante narra su sobrecogimiento al ver la procesión simbólica de almas nobles que siguen a un mensajero del cielo luego de cantar tres veces: Veni, sponsa, de Libano (Purg. XXX 1-11). Estas palabras parecen ser una alusión a Beatriz. Les sigue a estas expresiones otras de bienvenida como Benedictus qui venis! Es decir, el poeta prepara la llegada de Beatriz de una manera solemne y la belleza de este canto no es indiferente.

Contemplando del día el fiel retorno, / vi la parte oriental toda rosada / y el otro cielo con sereno adorno; / la faz del sol nacía sombreada, / tanto que, por templarla los vapores, / podía

13. Sustentaría su refutación, por ejemplo, con perspectivas como la de Roland Barthes, quien en La muerte del autor plantea que en los textos literarios no necesariamente se da la correspondencia entre el yo de quien escribe, usualmente concebido como autor, con el yo que narra o con el yo que actúa dentro de un relato. Y mucho menos quien lee debe darse a la tarea de considerar la búsqueda del "sentido profundo" que habría plasmado dicho autor, pues es, justamente, este autor-Dios, autor-Padre, ese autor como fundamento, el que debe dar lugar al lector y a las múltiples interpretaciones posibles: "La muerte del autor se paga con el nacimiento del lector" (Cf. Barthes, 1987, p. 71).

14. Las palabras del mismo Dante son: "Y en verdad que desde entonces puedo decir que el amor se enseńoreó de mi alma, uniéndome tan íntimamente a ella y tomando sobre todo mi ser tal ascendiente, en virtud del mismo vigor que mi imaginación le comunicaba, que me sentí forzado a prestarle completa obediencia. En tal situación, sentirme como secretamente impelido a ir en busca de aquel ángel de juventud (...)" (Alighieri, 1876, p. 9). Y también escribe Boccaccio: "Casi a finales de su vigésimo cuarto año, Beatriz, como dispuso Dios que todo lo puede, dejando las angustias de este mundo, partió hacia la gloria que sus méritos le habían proporcionado. A consecuencia de esa partida, Dante quedó sumido en tanto dolor, en tanta aflicción, en tantas lágrimas, que muchos de sus cercanos, parientes y amigos creyeron que solamente la muerte acabaría con ellas y consideraron que sería inmediata, al verlo sin ninguna confortación, sin que le hiciera efecto ningún consuelo" (Boccaccio, 2016, p. 78).

15. Siguiendo las aportaciones del crítico y traductor de la obra de Dante, Ángel Crespo, la Comedia puede leerse en forma literal, simbólica, teológica, política, filosófica y poética (Crespo, 1999, p. 76). Además, Crespo desarrolla un análisis poético-literario de la Comedia y, estimando en gran medida la influencia del poeta romano Ovidio, sostiene la tesis según la cual para Dante "el hombre es un ser metamorfoseable por naturaleza" (p. 130). Aspecto que señala no solo las diversas transformaciones que tienen los personajes que habitan las tres regiones del más allá, sino la propia y progresiva conversión de Dante comenzando con la oscuridad de sí al inicio del Infierno hasta su ascensión al Paraíso. 
resistirla la mirada: / en una nube, así, de bellas flores / que un angélico coro esparciendo iba / y vertió dentro y fuera sus colores, / ceñido el blanco velo con oliva, / una mujer surgió con verde manto, / vestida de color de llama viva. (Purg. XXX 22-33)

Y Dante, absorto y maravillado, expresa el antiguo sentimiento del amor potente en su interior. A continuación, expresa que Beatriz ha sido desde que la conoció en su infancia, un modelo de alta virtud, "virtud que hiere la vista" (Purg. XXX 40-41) y ante esto no puede más que voltear la mirada, como quien manifiesta con el gesto la vergüenza.

En ese canto ya Virgilio está ausente y queda nuestro poeta ante la contemplación de su Beatriz. ¿Acaso existe, en toda la literatura, expresión más vasta de la felicidad, felicidad del reencuentro con el amor perdido, felicidad de haber superado la muerte, de haber purgado sus pasiones hasta volver a encontrar su único y sublime amor?: "Mírame bien, que yo soy Beatriz! ¿Cómo has subido tan osadamente? ¿No sabes tú que el hombre aquí es feliz?" (Purg. XXX 73-75). Dante muestra siempre ante la imagen de su amada un sentimiento de vergüenza (Purg. XXX 78), vergüenza que en la perspectiva que hemos planteado con la proyección de valores, es el pudor del mismo Dante ante sí. En adelante, Beatriz habla de su influencia en la conversión de Dante: "Con mi rostro algún tiempo le he auxiliado: / mostrándole los ojos jovenzuelos, / conmigo al buen camino le he llevado (Purg. XXX 121-123)". Los últimos versos refieren a Virgilio y reconoce Beatriz su papel de guía. Termina el canto aludiendo Beatriz a la importancia, para Dante, de olvidar la vida mundana y de purgarse para lograr avanzar hacia el cielo. ${ }^{16}$

Por otro lado, en Paraíso III y IV, el cielo de los espíritus débiles, se encuentra Dante con la monja y beata Picarda Donati, que se halla en el cielo más lejano de Dios por haber faltado a sus votos religiosos, y tras sostener un diálogo sobre la doctrina de Platón en el Timeo y luego sobre el libre albedrío, Dante se muestra perplejo por su limitada comprensión. Y es en este momento cuando expresa: "Me miró Beatriz con ojos llenos / de unos rayos de amor tan encielados / que mi virtud huyó, venida a menos, / y zozobré, los ojos inclinados." (Par. IV 139-142).

El punto clave que nos interesa es la significación de la mirada y la actitud que muestra Dante: "los ojos llenos e iluminados de amor" es la idealización del amor de Dante. Pero este amor no es, de ninguna manera, corporal o erótico, puesto que sostener esto sería limitar la pureza de la beatitud de Beatriz allí, en la cercanía de Dios, y aludir a una corporeidad que no se corresponde con la trascendencia espiritual que supone la ascensión del poeta al cielo en este contexto moral. En este punto se enfrentan la simbología de un amor espiritual con la consciencia del poeta por pertenecer al mundo, pues en este viaje por las tres regiones del más allá, Dante no es un alma, es un cuerpo porque está vivo. Esta presencia viva ${ }^{17}$ de Dante en el Infierno, Purgatorio y Paraíso, reiteramos, solo es entendible desde el plano poético y simbólico. Esa mirada de la Beatriz que amó, entonces, está tan llena de virtud y beatitud -palabras femeninas- que Dante siente desfallecer y

16 Llama la atención, por último, un elemento simbólico extraído de la numerología. Dejando de lado el canto I, que según la tradición es una suerte de proemio, es interesante que al cabo del Canto XXX, el Dante poeta ha narrado 63 cantos y sucede lo mismo con la travesía del Dante héroe. En ese mismo sentido, a ambos, Dante poeta y Dante héroe, les resta 36 cantos para culminar el viaje. Se trata de la simbología del número 9 representado en la figura de Beatriz. La suma de los números $6+3$ equivale a 9 y los 36 cantos que faltan muestran la misma equivalencia: $3+6$ es igual a 9. Interpreto que de inicio a fin y del fin al inicio, está presente el número 9 y con ello los valores que encarna Beatriz: el amor, la fe, la beatitud. Pero, como bien se lee, puede interpretarse esta numerología como el apoyo incondicional de Beatriz hacia Dante, pues ella estuvo en su vida terrenal, bajó hasta el Infierno y lo acompańa ahora en su bienaventuranza. No cabe duda de que este canto es el lugar y el momento perfecto para la irrupción de Beatriz. (Para un estudio sobre la numerología en Dante. Cf.: Guénon, R. 2005. El esoterismo de Dante. Paidós, Barcelona).

17. “(...) mi alma, que fugitiva entonces era, / volvióse a contemplar de nuevo el paso / que no atraviesa nadie sin que muera." (Inf. I 25 y ss.) 
baja la mirada. Baja la mirada, justamente, porque no está al nivel de dichos valores. ${ }^{18}$ No los tiene aún, pero los desea a modo de ensoñación idealizadora.

Cabe advertir que el nombre propio Beatrix significa en latín "rica-feliz" y tiene relación con el adjetivo beatus, que indica "colmado de bienes". En consecuencia, lo más elevado para la vida humana se representa en Beatriz, la felicidad como el mayor de los bienes. ${ }^{19} \mathrm{Y}$ es que Dante figura, a menudo, en Beatriz, la sonrisa. De hecho, todo el Paraiso está lleno de luz y sonrisas, ${ }^{20}$ bien como señal de compasión (Par. II, 49-57), bien como símbolo de la plenitud del alma y felicidad por la liberación del poeta.

Yo era siervo y me has dado libertad / por cuenta vía y modo vio tu ciencia / que tenías de hacerlo potestad. / En mí custodia tu magnificencia, / y mi alma se desnude, por ti sana, / del cuerpo con tu santa complacencia. / Así recé; y aquella que lejana / parecía, riéndose miróme; I y se volvió hacia la eterna fontana. (Par. XXXI 85-93)

Estos versos constituyen el sumun de los valores que Dante proyecta en su donna idealizada. Primero, la libertad; segundo, la salud del alma; tercero, la sonrisa de Beatriz, que significa el bienestar que transmite la felicidad idealizada. Todos estos valores se expresan tanto en toscano como en español en femenino. ${ }^{21} \mathrm{Al}$ respecto de la sonrisa, Borges (1982), dirá en La última sonrisa de Beatriz, que ese último gesto que Beatriz dispensa a Dante antes de elevarse a la eterna y aureolada fuente de luz, tiene que ver con la prolepsis de la ya inevitable visión de Dios, pues "Dante le reza como a Dios, pero también como a una mujer anhelada. Beatriz, entonces, lo mira un instante y sonríe, para luego volverse a la eterna fuente de luz" (p. 81).

La idealización de la felicidad, la libertad y la salud del alma son los valores centrales que construye Dante en la Comedia, obra que nos muestra expresamente el cambio desde ese estado de oscuridad en que inicia su travesía: "A mitad del camino de la vida / yo me encontraba en una selva oscura, / con la senda derecha ya perdida." (Inf. I, 1-3), hasta la contemplación de la luz divina: "Y la alta fantasía fue impotente; / mas a mi voluntad seguir sus huellas, / como a otra esfera, hizo el amor ardiente / que mueve al sol y a las demás estrellas" (Par. XXXIII, 142-145).

De manera más precisa, Dante ha pasado de un estado de oscuridad de sí, esto es, de ignorancia y pasiones terrenales, mediante un proceso de transformación espiritual gradual hasta lograr la ascensión al Paraíso como alma clara y pura. Y en atención a los

18. "Entre tanta virtud, entre tanta ciencia como he mostrado que tenía este admirable poeta, la lujuria encontró un amplísimo espacio, y no solamente en sus años más jóvenes sino también en los maduros." (Boccaccio, 2016, p. 108). Relevante resulta aquí seńalar también las notas de Crespo de los versos de Infierno I, 32-60, en donde Dante refiere su encuentro con las tres fieras que lo apartaron del camino recto, a saber, el leopardo, el león y la loba. Crespo señala: "El leopardo es un símbolo de la lujuria, vicio que, al parecer, fue el primero que apartó a Dante de la virtud"; y luego, "El león en este contexto, es un símbolo de la violencia o de la soberbia. Pudiera ser una alusión a que la vida política de Dante fue otra de las causas que le apartaron del ideal cristiano de vida". Y "La loba parece un símbolo de la incontinencia, de los deseos violentos y de la avidez de riquezas, es decir, de la codicia. Estos tres animales representan tanto los vicios que condicen a la perdición eterna, como las fuerzas maléficas y procedentes de los demás que se alzaron contra Dante y lo hostigaron durante su vida" (Crespo, 1977 p. 52-53).

19. En Dante y la filosofía, Étienne Gilson escribe sobre la figura de Beatriz como signo de felicidad: "Aun suponiendo que Dante haya admitido que hay una sola beatitud, no se ve claramente lo que esto probaría en lo concerniente a Beatriz. El hecho de que este nombre signifique "beatitud" no permite concluir que no haya existido una mujer que llevara ese nombre y que fuera amada por Dante. Se puede amar una mujer que se llame Beatriz; incluso se la puede amar, entre otras razones, porque se llama Beatriz; en fin, se puede amar a una mujer, y llamarla Beatriz, porque uno encuentra su felicidad al amarla y porque ese nombre quiere decir: la que da la felicidad; pero nada de esto puede tener el efecto de suprimirla" (Gilson, 2011, p. 17).

20. En Dante y su obra, Ángel Crespo señala que el Paraíso es el reino de la luz, de esa luminiscencia que viene buscando Dante desde la selva oscura.

21. En el vocabulario toscano-castellano de Christoval de las Casas (1570), la palabra felicidad se escribe Felicità. De igual manera, se lee allí libertà (libertad) y sanità (sanidad). Todos estos vocablos conservan el femenino tanto del italiano actual como del espańol. De igual forma, los términos que usa Dante en este pasaje en toscano son: "la virtute", "a libertate", "l'anima" (Par. XXXI,84-90) 
versos de Paraiso XXXI citados arriba, reconoce ahora que ha sido Beatriz quien lo ha liberado de la ignorancia, de la oscuridad; que lo ha orientado por el camino que conduce a Dios. Y esa experiencia de contemplar a Dios, esa experiencia de la elevación espiritual y moral, es la continuación de la idealización de los valores que obtuvo gracias a la ensońación idealizadora sobre Beatriz. Dante, por lo tanto, no solo proyecta estos valores en su poema sacro, sino que con ello consigue apropiarlos, se transforma a sí mismo, se purga espiritualmente a través de la escritura poética: ‘acaso no tendría razón Ángel Crespo cuando afirmaba que "para Dante el hombre es un animal metamorfoseable por naturaleza”? (Crespo, 1999, p. 130.)

Nótese, para finalizar, que los valores que hemos señalado son femeninos: la virtud, la felicidad, la beatitud, la plenitud, la libertad y que estos son proyecciones en anima que se representan de manera poética gracias al deseo. Y por lo tanto, esta interpretación conviene en la medida en que si Beatriz es la beatitud y en consecuencia la felicidad, entonces con ello podemos darle una explicación al título mismo del poema dantesco: Comedia, pues lo cómico es mucho más cercano a la felicidad que lo trágico. Pero sobre esto habrá de juzgar el lector.

\section{Conclusiones}

La comprensión de la figura de Beatriz en la Comedia de Dante Alighieri, ha de darse no asumiendo su literariedad narrativa ni asentando el criterio de su historicidad, sino indagando en su significación poética y psicológica. Ello implica la importancia de hacer una lectura de inmersión procurando identificar -independientemente de si Beatriz fue una persona histórica o no- la correspondencia entre los deseos (idealización) del poeta con sus proyecciones literarias (ensoñación poética). Así es como concebimos a Beatriz, como una representación poética idealizada del propio yo dantesco siendo la poesía ese espacio de creación de sí, de autopoiesis, en la que obtiene y realiza sus deseos más loables, como la sabiduría, la virtud, la beatitud. Por eso, la ascensión de Beatriz al Paraíso es un símbolo de la katarsis dantesca, es la purificación, es su liberación del pecado, es la felicidad.

En síntesis, esta comprensión ha sido posible para nosotros gracias a los planteamientos teóricos de Bachelard y Jung, con los cuales se pudo reconocer hermenéuticamente en la poiesis dantesca, el trazo de una proyección idealizada en Beatriz de los valores que el mismo Dante deseó y que, al fin y al cabo, obtuvo en plano poético con su llegada triunfal al empíreo y su espléndida contemplación de Dios. Finalizamos este estudio con una cita de Bachelard que condensa todo lo expuesto en estas páginas:

Sin duda cometería un error el soñador que quisiera pasar de Berenice a Beatriz, del relato barresiano de pobre sensualidad a la mayor de las idealizaciones de los valores humanos de Dante. Al menos nos llama la atención que el propio Barres haya buscado esta idealización. No ignoraba el problema planteado por la filosofía de Dante: ¿̨eatriz no representa acaso la mujer, la iglesia, la teología? Beatriz es una síntesis de las más grandes idealizaciones: para un soñador de los valores humanos representa el Anima sabia. Resplandece por el corazón y por la inteligencia. (p. 148)

\section{Referencias}

Alighieri, D. (2011). Comedia. Edición bilingüe, Traducción de Ángel Crespo, Seix Barral: Barcelona.

Alighieri, D. (1876). La vida nueva. Biblioteca Universal, Tomo XXI: Madrid.

Bachelard, G. (2014). La poética de la ensoñación. FCE: México.

Barthes, R. (1987). El susurro del lenguaje. Paidós: Barcelona. 
Bejarano, S. (2006). El ánima como impulso vital del ensońador de palabras. Universidad Autónoma de Occidente. En Revista Habladurías No. 5, p. 62-79. https://red.uao.edu.co/ handle/10614/74

Boccaccio, G. (2016). Breve tratado en alabanza de Dante Alighieri. Edición Bilingüe.

Borges, J. (1982). Nueve ensayos dantescos en La última sonrisa de Beatriz. Ahkenaton, versión ePub.

Casas, C. (1570) Vocabulario toscano-castellano. Edición electrónica.

Collazos, E. (2013) Por la ciudad del fuego. En revista Poligramas 38, segundo semestre 2013, ISSN 0120-4130. file://C:/Users/USUARIO/Downloads/Dialnet-PorLaCiudadDelFuego-7528507.pdf

Crespo, A. (1999). Dante y su obra. Acantilado: Barcelona.

Diccionario VOX latino-espańol, español-latino, Barcelona (1982).

Gilson, E. (2011). Dante y la filosofía. Eunsa: España.

Ginés, B. (2012). Beatrice Portinari como esencia de inspiración. El caso de Dante Alighieri y Dante Gabriel Rossetti. Universitat de Valencia. Saitabi. Revista de la Facultat de Geografia i Historia, 62-63 (2012-2013), pp. 317-329. https://roderic.uv.es/handle/10550/39427

Guénon, R. (2005). El esoterismo de Dante. Paidós, Barcelona.

Jung, C. (1970). Arquetipos e inconsciente colectivo. Paidós: Barcelona.

Louzada, P. (2019) Dante Alighieri e a voz femenina sobredeterminada: agonismo e fantasmagoria. Lingüistica y literatura ISSN 0120-5587. E-ISSN 2422-3174 N 76, 2019, 201-218. Universidad Federal de Goiás (Brasil). DOI: doi.org/10.17533/udea.lyl.n76a09

Miller, K. (2009). ¿Quién es Beatriz? Las cualidades de una mujer. En Revista Realidad 120. DOI: https://doi.org/10.5377/realidad.v0i120.3398

Santayana, G. (1943). Tres poetas filósofos. Lucrecio, Dante, Goethe. Losada: Buenos Aires.

Scrimieri, R. (2001). La analogía Beatriz-Cristo. Universidad Complutense de Madrid. En Cuadernos de Filología Italiana n. ${ }^{\circ}$ 8: 65-77. file://C:/Users/USUARIO/Downloads/18411Texto\%20del\%20art\%C3\%ADculo-18487-1-10-20110602.PDF

Scrimieri, R. (2008). Imágenes y visiones de Beatriz. Universidad Complutense de Madrid. En Revista Tenzone $\mathrm{n}^{\circ}$ 9. http://webs.ucm.es/info/italiano/acd/tenzone/t9/scrimieri.pdf 